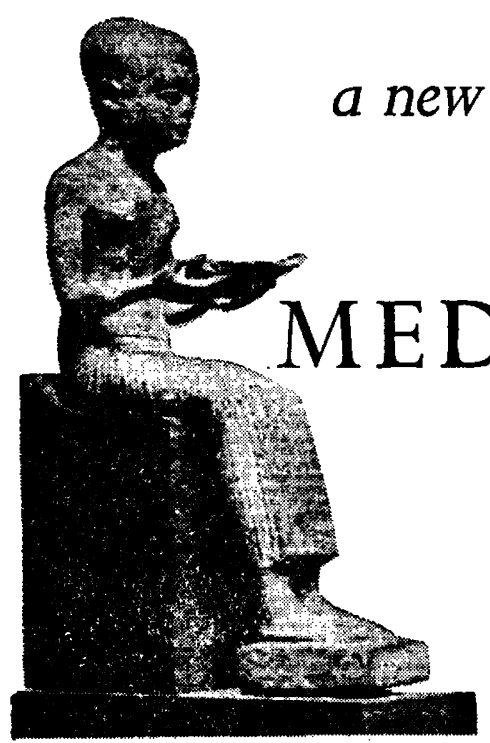

A Partial Table of Contents

Foreword:

ON THE SPOKEN WORD

I: THE FABRIC OF MEDICINE Concept, Methods and Scope of the History of Medicine-Medical Geography-Paleopathology

II: PRELUDE OF MIST / Witch Doctors, Shamans, Medicine Men (Primitive and Magic Medicine)

III: A TALE OF THREE RIVERS

Priests and Sorcerers (Archaic Medicine-Mesopotamia and Egypt) IV: SONG OF THE MARE NOSTRUM / Philosophers and Physicians (Medicine in Classical Greece and Imperial Rome)

V: DAWN AT MIDNIGHT Byzantine Healers, Arabian Hakims, Monks, Crusaders, and Medieval "Doctors" (Byzantine, Arabian, Monastic, and University Medicine)

VI: THE SMILE OF THE REBEL Artists, Adventurers, Physiks and Barbers (Renaissance Medicine)

VII: THREE WINDOWS TO MEDICAL HISTORY / Experimenters, Teachers, and Theoreticians (Medicine in the Baroque, Enlightenment, and Romanticism Ages)

VIII: THE VAST THRESHOLD Investigators, Clinicians, Psychiatrists, and Space Physicians (Medicine in the Twentieth Century)

Epilogue: TO BE A DOCTOR

Recommended Reading / Nobel Prize Laureates / Selected Medical and Historical Chronology / Index

\section{book of vital interest}

\section{A PRELUDE TO ICAL HISTORY}

by FELIX MARTI-IBAT̃NEZ, M.D.

Editor-in-Chief of the Medical Newsmagazine, $M D$;

Professor and Chairman, Department of the

History of Medicine, New York Medical College

$T$

he colorful and stirring saga of medicine, as told in this enlightening new book, embodies a stimulating concept in the writing of the history of medicine. Reflecting the author's lifelong enthusiasm for this discipline, A Prelude to Medical History traces the evolution of medical ideas in relation to the history of civilization, capturing the romance and magnificence of the vast panorama of medicine. In telling the epic of the physician through the ages, the author brings to life through the magic of story-telling, the places and times, persons and events, from prehistory to the present, which framed the great moments of the history of medicine. For physicians, educators, students, and all those interested in this important facet of man's cultural heritage, this book promises a surprising new enjoyment of the splendid pageant of medicine.

253 PAGES / CLOTH BOUND / \$5.75

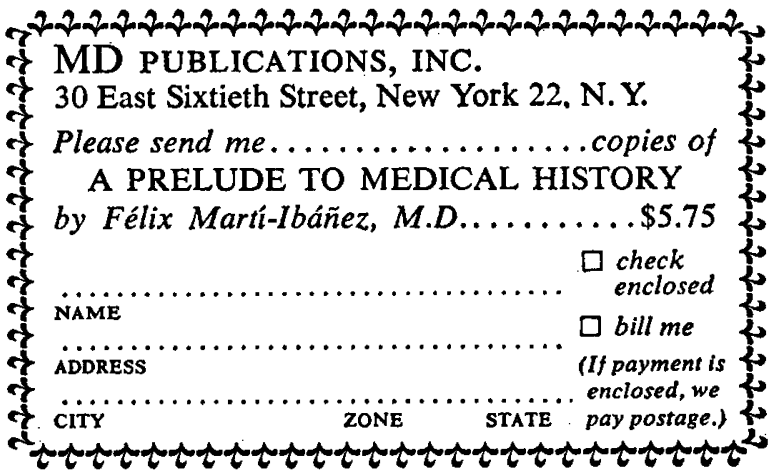




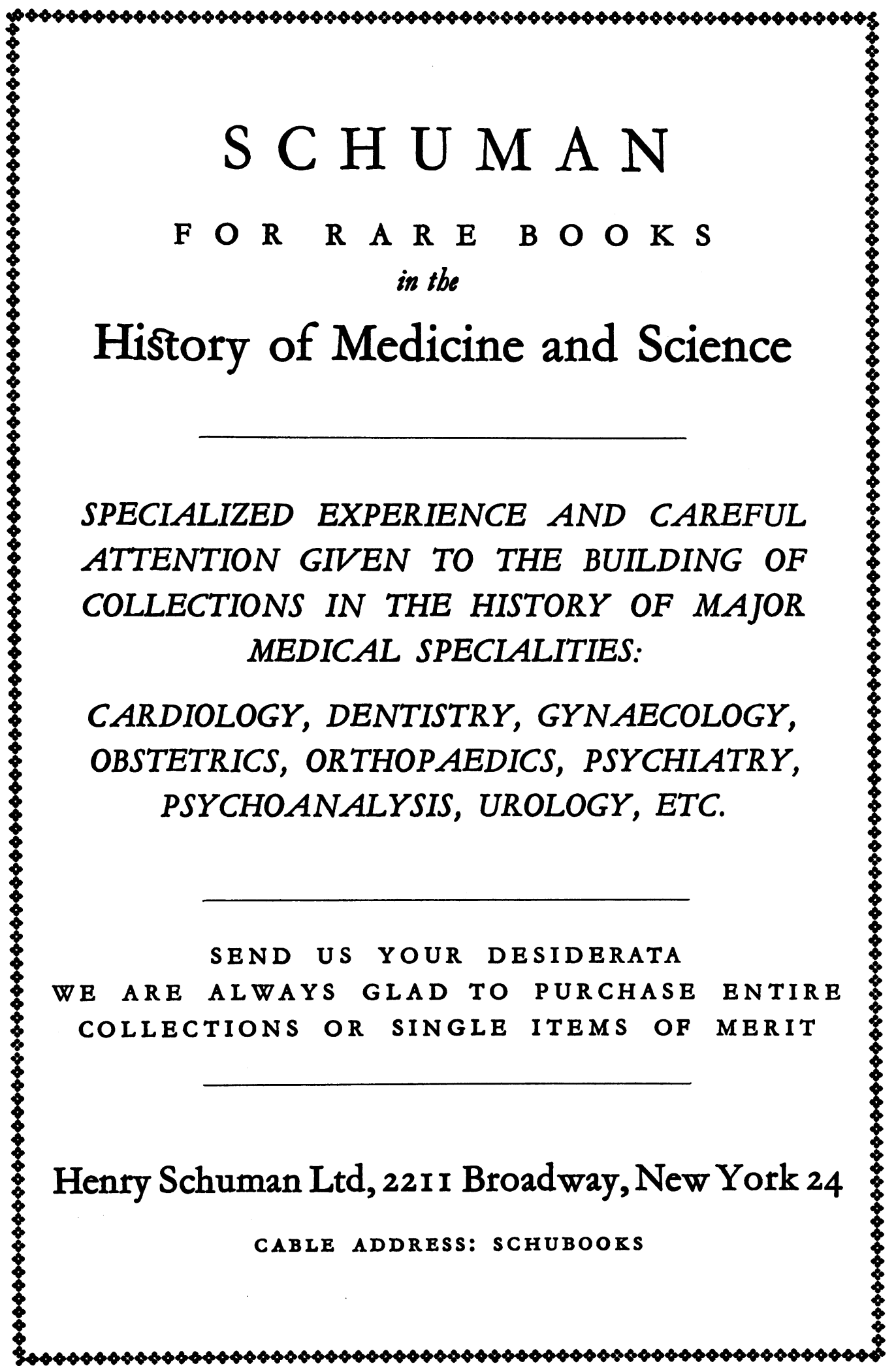


Rare and Important Books

Illustrating the

History OF ScIENCE

AND MBdicine

Biographies AND Autograph

LETTERS OF SCIBNTISTS AND

Medical Men

Catalogues on above subjects free on application

Hugh OK. Elliott Ltd. P.O. BOX 284

199 PICCADILLY

LONDON, W.1

Telephone: CUNningham 0724

Business by post or appointment only

\section{Famous}

\section{IIInesses in}

History

\section{R. SCOTT STEVENSON \\ M.D., F.R.C.S.}

'Recommended without hesitation ... he has thrown his net wide, ranging from Charles II to President Roosevelt.'

Dr W. A. R. Thomson, Financial Times

'The author has been careful in ascertaining the facts, has often looked at original sources, and, like a good surgeon, usually comes to a definite diagnosis on the nature of the illnesses. He is frank in his comments on the medical attendants.' British Medical Journal

EYRE \& SPOTTISWOODE $21 \mathrm{~s}$

\section{The Joumal of}

JAMES YONGE, PLYMOUTH SURGEON (1647-1721)

James Yonge began his medical career at the age of eleven, as a surgeonapprentice in the navy. His work took him to places as far apart as Newfoundland and Holland, and to many parts of England. His journal is a lively record of his impressions and experiences, combining everyday incidents, such as a wedding party, a cold winter journey, or the death of a patient, with events of real historical interest, such as his experiences in a Dutch prison, his visit to London just after the Great Fire, and his unique account of the viva voce examination at the College of Physicians. By the time he ended his journal he was one of the best-known surgeons in England, specialising in amputations and in the cure of fistulas (fee 50 shillings each!) $35 \mathrm{~s} \mathrm{net.}$ 


\section{E. WEIL}

Old and Rare Books-

Old Science and Medicine

c/o National Provincial

Bank

9 Market Place,

London, N.W.11

$$
\star
$$

now ready:

Catalogue 31

SCIENCE AND MEDICINE

XIXth and XXth century

\section{Medical Books}

Prints Manuscripts

Portraits

Old, Rare, and Out-of-print

AMERICA'S LARGEST STOCK

A vast stock, fully catalogued and classified, American and European, dating from $X V$ to $X X$ Centuries, particularly classical and unusual works, with emphasis upon history, biography, and specialized medicine. Lists issued in all fields of medicine. Permanent back-order files maintained.

ARGOSY BOOK STORES

114 E. 59th St., N.Y. 22, N.Y. PL 3-4455
Psychiatric Monograph Series No. 3

A Treatise on Madness

By WILLIAM BATTIE, M.D. and

Remarks on Dr Battie's

Treatise on Madness

By JOHN MONRO, M.D.

A Psychiatric Controversy of the 18th Century Introduced and Annotated by

RICHARD HUNTER, M.D., M.R.C.P., D.P.M.

and IDA MACALPINE, M.D., M.R.C.P.

8vo Ilustrated Cloth

In one volume

50s. net

\section{Dawsons of Pall Mall}

16 Pall Mall, London, S.W.1
MEDICINE

\section{AND SCIENCE}

We carry a considerable stock of books of historical interest on these subjects, and shall be glad to send a list on request. $\star$

G. W A L F O R D 186 Upper St., London, N.1 


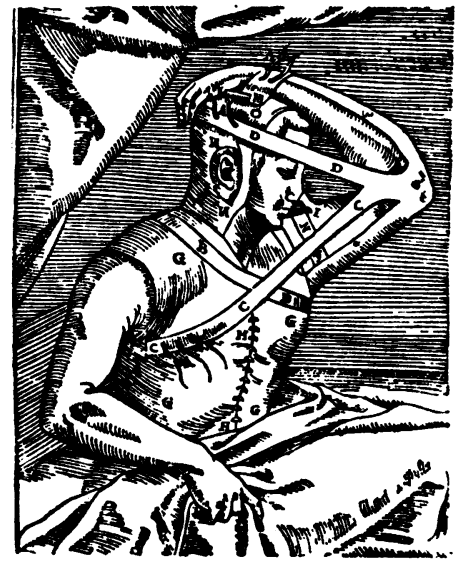

A sixteenth-century nose graft

\title{
A Short History of Medicine
}

\author{
F. N. L. Poynter, Ph.D., F.R.S.L., \\ F.L.A.
}

(Chief Librarian, Wellcome Historical Medical Library)

and

K. D. Keele, M.D., F.R.C.P.

“Remarkably comprehensive." THE LANCET

"In this book much wisdom and knowledge has been compressed."

BRITISH MEDICAL JOURNAL

“Deserves the greatest respect and admiration." MD (NEW YORK)

"Excellent volume." JOURNAL OF THE AMERICAN MEDICAL ASSOCIATION

The authors trace the development of medicine from primitive times to the present day, with biographical notes on outstanding medical figures and a consideration of the properties and uses of some of the better known drugs.

The first part of the book, "Medicine and the Individual", deals with the doctor's relation to his patient and the development of knowledge and understanding of the structure and function of the body; the second part, "Medicine and the Community", discusses the growth of preventive and social medicine as agents in the promotion of a healthy society.

160 pages; 12 plates, illustrating important scientific advances or depicting health conditions at certain periods; $17 \mathrm{~s} .6 \mathrm{~d}$. net.

\section{MILLS \& BOON LTD. \\ 50 Grafton Way, London, W.I}

